\title{
Purification of drinking water by low cost method in Ethiopia
}

\author{
Yasabie Abatneh • Omprakash Sahu • \\ Seid Yimer
}

Received: 23 October 2013/ Accepted: 17 December 2013/Published online: 5 January 2014

(C) The Author(s) 2014. This article is published with open access at Springerlink.com

\begin{abstract}
Nowadays, water treatment is a big issue in rural areas especially in African country. Due to lack of facilities available in those areas and the treatment are expensive. In this regard's an attempt has been made to find alternative natural way to treat the rural drinking water. The experiment trials were undertaken on the most promising plant extracts, namely: Moringa oleifera, Jatropha curcas and Guar gum. The extracts were used to treat contaminated water obtained from a number of wells. The results showed that the addition of $M$. oleifera can considerably improve the quality of drinking water. A $100 \%$ improvement both in turbidity and reduction in Escherichia coli was noted for a number of the samples, together with significant improvements in colour.
\end{abstract}

Keywords Coagulants $\cdot$ Moringa oleifera $\cdot$ Plant extracts . Shallow wells

\section{Introduction}

Water is a major need on the earth, without it life is impossible. About 1 billion people are without safe drinking water worldwide. The vast majority of these people are located in sub-Saharan Africa, South Asia and East Asia. Countless lives are lost annually due to drinking and using contaminated water (WHO 2006). The people at greatest risk are children, people living under unsanitary conditions and the elderly (WHO 2006). Globally, 4 billion cases of diarrhoea are reported every year causing 1.8 million deaths, out of

Y. Abatneh · O. Sahu $(\bowtie) \cdot$ S. Yimer

Department of Chemical Engineering, KIOT, Wollo University, Kombolcha, Ethiopia

e-mail: ops0121@gmail.com which about $90 \%$ are children under five (UNESCO 2007). In Ethiopia, the diarrhoea morbidity is around $17 \%$ (Masangwi et al. 2008). The most common source of drinking water for the rural people is groundwater from boreholes (deep wells), shallow wells and springs (Dzwairo et al. 2006). Groundwater is usually consumed without any form of treatment. Water is a medium of thousands of microorganisms some of which are disease-causing. Pathogens (e.g. bacteria, viruses, protozoa and helminths) in water cause a variety of diarrhoea-related diseases such as cholera. These pathogens are commonly derived from human faecal material. Approximately 2.2 billion people are without adequate sanitation in the world. In Ethiopia, the majority of people in rural areas and high density townships in urban areas use pit latrines which are often in a state of disrepair and unhygienic (Lungu et al. 2008). In the rainy season, faecal matter from pit latrines and open sources is washed into water bodies, thereby contaminating the water (Dzwairo et al. 2006). In urban areas, sanitation facilities fill up and overflow if they are not properly managed. Microbiological water quality from shallow wells (with depths not exceeding $20 \mathrm{~m}$ ), has been found to be more inferior in the wet season compared to the dry season (Pritchard et al. 2007, 2008).

Conventional water purification systems using imported chemicals are prohibitively expensive for developing countries. Ethiopia being a developing country where $52.4 \%$ of people live below the poverty line (World Bank Annual Report, 2013), such expensive conventional methods of assuring potable water quality are unsustainable. In addition to the high cost of importing water treatment, chemicals like aluminium sulphate (Alum), a common coagulant, a number of researchers have also found out that its residue in water may be carcinogenic (Litherland 1995). As a result, people use untreated water from borehole/ shallow wells, which pose a threat to their health. 
Natural plant extracts have been used for water purification for many centuries. Most of these extracts are derived from the seeds, leaves, pieces of bark or sap, roots and fruit extracts of trees and plants (Anwar and Rashid 2007), For example, Strychnos potatorum was being used as a clarifier between the fourteenth and fifteenth centuries BC. Shulz and Okun (1984) together with Sanghi et al. (2006) reported that seeds of the nirmali tree (Strychnos potatorum) were used to clarify turbid river water 4,000 years ago in India. It is further reported that in Peru, water has been traditionally clarified with the mucilaginous sap of tuna leaves obtained from certain species of cacti. Zea mays was used as a settling agent by sailors in the sixteenth and seventeenth centuries.

Natural coagulants have been reported to have several advantages compared to Alum (Aho and Lagasi 2012). Natural coagulants produce much lower sludge volume, the natural alkalinity is not consumed during the treatment process, they are biodegradable, safe to human health, cost effective since they can be locally grown and have a wider effective dosage range for flocculation of various colloidal suspensions (Sanghi et al. 2006). Moringa oleifera is medicinal species, belonging to monogeneric family Moringaceae (order Brassicales). It has 33 species of trees and shrubs distributed in sub-Himalayan ranges of India, Sri Lanka, North Eastern and South Western Africa, Madagascar and Arabia (Francis and Liogier 1991; The plant list, 2010). Today, it has become naturalised in many locations of the tropics and is widely cultivated in Africa, Ceylon, Thailand, Burma, Singapore, West Indies, Sri lanka, India, Mexico, Malabar, Malaysia and the Philippines (Fahey 2005).

Bacterial removal in the range of $90-99 \%$ by the powder has also been reported (Madsen et al. 1987). Yongabi (2008) tested the coagulative and disinfective capabilities of M. oleifera, Jatropha curcas, Pleurotus tuberrregium sclerotium, Hibiscus sabdariffa and Alum on wastewater samples. M. oleifera coagulated about $90 \%$ of the particles in the samples. The coagulation effect was superior in heavily polluted water than less polluted water. The number of coliforms also reduced substantially. It has been also used as water softener (Muyibi and Evison 1995)

The aim of drinking water treatment is to remove impurities and bacteria in order to meet the quality guidelines for drinking water (WHO 2004). M. oleifera seeds are recommended for eco-friendly, nontoxic, simplified water treatment where rural and peri-urban people living in extreme poverty (Mangale et al. 2012). Though previous studies reported the use of $M$. oleifera seeds for water purification, (Anwar and Rashid 2007; Broin et al. 2002; Kalogo et al. 2000; Kawo 2007) the seeds under study exhibited resistance to some of the waterborne pathogens (Onsare et al. 2013). In this regards, an effort has been made to establish a database of the naturally occurring coagulant that has been used for water purification and also to carry out preliminary tests on the performance of plant extracts available in Ethiopia on shallow well water.

\section{Materials and methods}

\section{Plant extracts}

The plant extracts database was produced from literature from different authors. The information on plant extracts included plant names, species, harvesting characteristics, where the plant is cultivated, climatic requirements, uses, estimated cost and other general information were documented.

\section{Preparation of powder and solution}

Good quality seeds (not rotten) of M. oleifera, J. curcas and Guar gum were ground using a domestic food processor. The powder was then sieved through a $600 \mu \mathrm{m}$ sieve. The solution was prepared by dissolving $10 \mathrm{~g}$ of powder in $100 \mathrm{ml}$ of distilled water. An appropriate volume of solution was then measured and poured in a $1,000 \mathrm{ml}$ of sample water for the desired concentration.

\section{Sampling}

Sampling equipments (filtration unit, forceps, Petri dishes, pipettes and medium) were sterilised using a portable Express Equipment Autoclave Steamer (for $15 \mathrm{~min}$ at $116{ }^{\circ} \mathrm{C}$ prior to use for microbiological tests). Flaming techniques using tissue paper soaked in $70 \%$ methanol were used to sterilise water discharge points for shallow wells fitted with hand pumps for $60 \mathrm{~s}$ (Paqualab Manual 2005; WHO 1997). To eliminate any stagnant water which could have stood in the service pipe, water was pumped to waste for at least $60 \mathrm{~s}$ (WHO 1997). Sample bottles were rinsed three times with source water to minimise the risk of external contamination before sampling (Paqualab Manual 2005). For open wells, the sample bottle was held by a metallic bottle holder then plunged into the well to a depth of $0.2-0.3 \mathrm{~m}$ below the water level to draw the water sample (WHO 1997; Paqualab Manual 2005). Microbiological analysis was carried out within $3 \mathrm{~h}$ after sampling so that the microbiological parameters did not change with time (AWWA 1995). Water samples were collected from five shallow wells from Kombolcha, Dessi, (Kombolcha open well and Dessi) and Chiradzulu (Hrbo, Kemssie and Sorabit). Initial turbidity levels of the well water were taken during sampling. These wells were chosen because of the high average faecal coliform counts from the previous 
Table 1 Total and faecal coliform results for studied wells

\begin{tabular}{|c|c|c|c|c|c|c|c|c|c|c|c|c|}
\hline \multirow[t]{4}{*}{ Well } & \multicolumn{4}{|c|}{ Total coliforms } & \multirow[t]{4}{*}{ Av. } & \multirow[t]{4}{*}{ SD } & \multicolumn{4}{|c|}{ Faecal coliforms } & \multirow[t]{4}{*}{ Av. } & \multirow[t]{4}{*}{ SD } \\
\hline & \multicolumn{4}{|c|}{ Season } & & & \multicolumn{4}{|c|}{ Season } & & \\
\hline & \multicolumn{2}{|l|}{ Dry } & \multicolumn{2}{|l|}{ Wet } & & & \multicolumn{2}{|l|}{ Dry } & \multicolumn{2}{|l|}{ Wet } & & \\
\hline & Aug & Oct & Feb & April & & & Aug & Oct & Feb & April & & \\
\hline Dessi & 2 & $5625^{\mathrm{a}}$ & 2,340 & 500 & 947 & 1,232 & 290 & $4775^{\mathrm{a}}$ & 610 & 30 & 310 & 291 \\
\hline Kombolcha & 3,350 & 26,000 & 23,950 & 10,400 & 15,925 & 10,871 & 2,600 & 8,700 & 28,450 & 2,000 & 10,438 & 12,384 \\
\hline Kemssie & 10 & 413 & b & 1,685 & 703 & 874 & 0 & 73 & 1,218 & 490 & 445 & 559 \\
\hline Hrbo & 65 & 1,350 & 4,320 & 5,820 & 2,889 & 2,645 & 35 & 438 & 1,015 & 630 & 530 & 408 \\
\hline Sorabit & 1,000 & 2,940 & 852 & 875 & 1,417 & 1,018 & 0 & 60 & 820 & 385 & 316 & 376 \\
\hline
\end{tabular}

Italics indicate open/unprotected well—all other wells are covered/protected

${ }^{a}$ Well was in state of disrepair (not being used)

${ }^{\mathrm{b}}$ Results were nullified

water quality analysis by Pritchard et al. (2007), (2008) as shown in Table 1. Kombolcha open well registered 10,438 faecal coliform counts on average from the previous analyses in 2006 and 2007. Faecal coliform counts for operational covered wells (Dessi, Kemssie, Hrbo and Sorabit) ranged from 0 to 1,218 . Samples for this study were collected in January and July, 2012.

Measurement of water quality parameters

Sedimentation jar tests which shown in Fig. 1 were used to determine the coagulation properties of the plant extracts used in this research programme. Five glass beakers of $1,000 \mathrm{ml}$ capacity were filled with raw water obtained for the selected shallow wells. One beaker was used as a control while the other four were dosed, with each plant extract in turn, with concentrations ranging from $50 \mathrm{mg} / \mathrm{l}$ to $500 \mathrm{mg} / \mathrm{l}$. Water samples were mixed at a high speed of 200 revolutions per minute for $60 \mathrm{~s}$, as recommended by Peavy et al. (1985). Rapid mixing for a few seconds is important after adding a coagulant to obtain a uniform dispersion of the coagulant and also to increase the opportunity for particle-to-particle contact. Subsequent gentle and prolonged mixing $(15 \mathrm{~min})$, which cements the microscopic coagulated particles into larger flocs, followed. The solution was then allowed to stand for $30 \mathrm{~min}$ to allow the coagulated particles to settle to the bottom. The supernatant was then filtered on Whatman filter papers no. 542. Turbidity of water was measured using a turbidity metre (ELE: 430-260). Turbidity was measured at extract concentrations ranging from zero (control) to $500 \mathrm{mg} / \mathrm{l}$. Faecal coliforms were only measured at optimum extract concentration to produce minimum turbidity. Faecal coliforms were determined using the membrane filtration technique. A measured volume of water as guided by WHO (2006) was filtered through a membrane. Membranes were

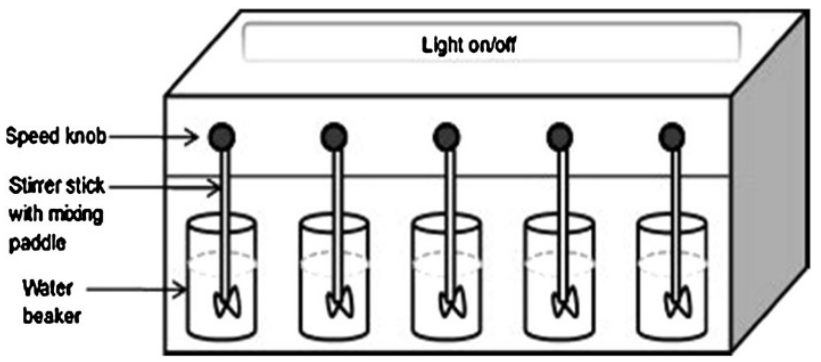

Fig. 1 Jar test equipment

then incubated on Membrane Lauryl Sulphate Broth (MLSB-reference OXOID MM0615) at $44{ }^{\circ} \mathrm{C}$ for $24 \mathrm{~h}$. Each test was duplicated and comparable results averaged, essentially to reduce any errors related to measurement. Bacteria that were present on the membranes grew into visible colonies. The viable colonies were counted and converted to represent a count per $100 \mathrm{ml}$.

\section{Results and discussion}

Effect of different extract on sample

The effect of extracts at initial turbidity of 49 NTU with $M$. oleifera, J. curcas, G. gum are shown in Fig. 2a-e. For water of relatively high initial turbidity, like that of Kombolcha of 49 NTU (Fig. 2a), M. oleifera produced the best results with an average percentage in turbidity reduction of $96 \%$. The optimum dosage for M. oleifera was $250 \mathrm{mg} / \mathrm{l}$ with a percentage reduction in turbidity of $100 \%$. G. gum was ranked second at an average turbidity percentage reduction of $95 \%$. The optimum dosage for $G$. gum was $50 \mathrm{mg} / \mathrm{l}$, corresponding to a turbidity reduction of $96 \%$. J. curcas had an average percentage reduction in turbidity of $90 \%$. The optimum dosage for $J$. curcas was 

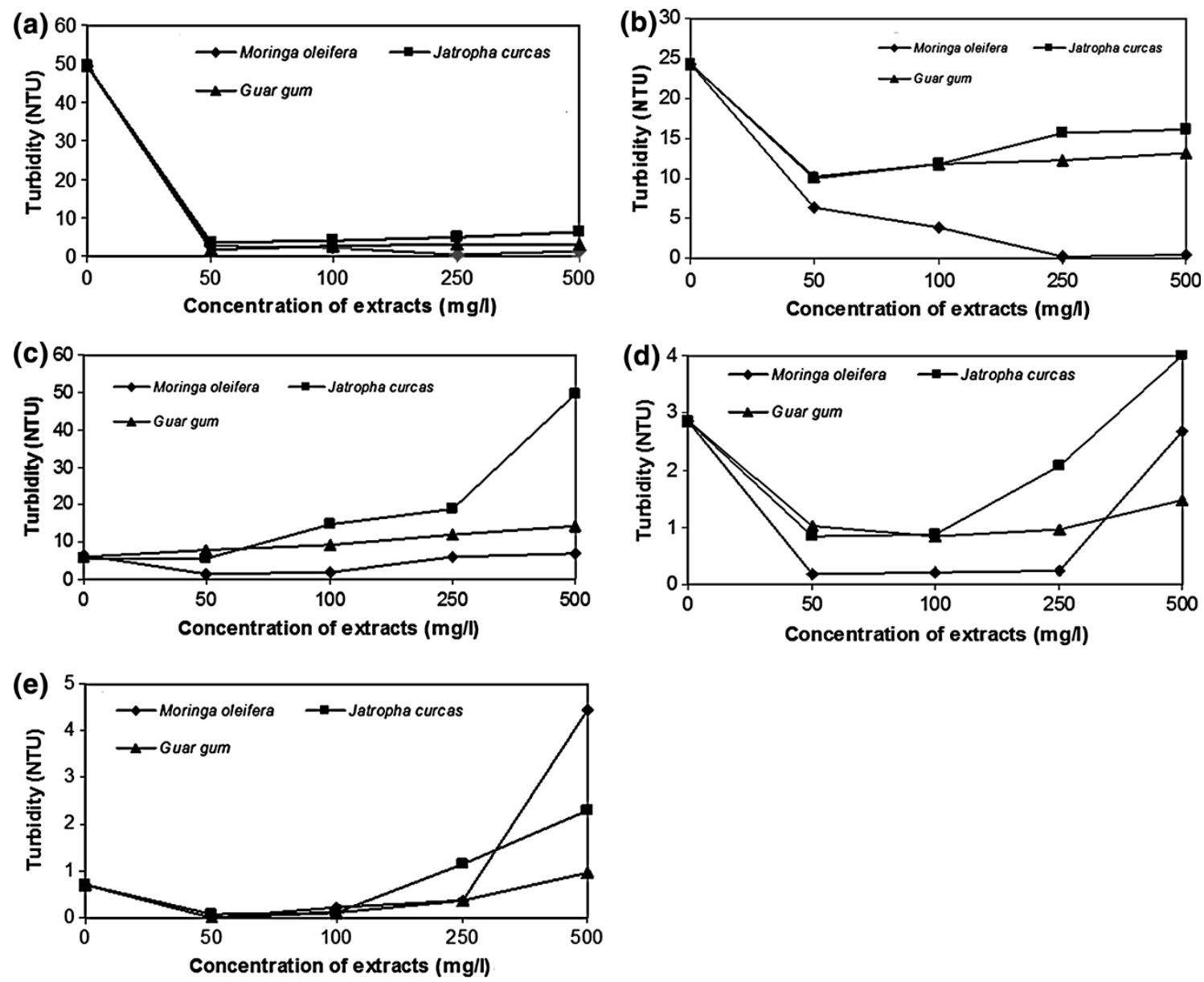

Fig. 2 a Effect of MO, JC, and GG on Kombolcha water at To $=49$ NTU. b Effect of MO, JC, and GG on Sorabit water at To $=49$ NTU. c Effect of MO, JC, and GG on Hrbo water at To $=49$ NTU. d Effect

also $50 \mathrm{mg} / \mathrm{l}$ with a turbidity reduction of $92 \%$. In general, all the extracts (M. oleifera, J. curcas, and G. gum) performed very well in this shallow well water with an average turbidity reduction of $94 \%$. Sorabit (Fig. 2b) had an initial turbidity of 24 NTU and Moringa reduced its turbidity by an average percentage of $89 \%$. The optimum dosage was $250 \mathrm{mg} / \mathrm{l}$ with a turbidity reduction of $99 \%$. G. gum was ranked second with an average turbidity reduction percentage of $52 \%$, at an optimum dosage of $50 \mathrm{mg} / \mathrm{l}$. Lastly, J. curcas reduced the turbidity of this water with an average percentage of $45 \%$, at an optimum dosage of $50 \mathrm{mg} / \mathrm{l}$.

The worst results were obtained with Hrbo water (Fig. 2c), which had an initial turbidity of 7 NTU for all extracts. The optimum dosage for M. oleifera for this water was $100 \mathrm{mg} / \mathrm{l}$ with a percentage reduction of turbidity of $75 \%$. Optimum dosage for $J$. curcas was $50 \mathrm{mg} / \mathrm{l}$, with a percentage reduction of turbidity of $10 \%$. Turbidity increased at all G. gum concentrations. Kemssie (Fig. 2d) had an initial turbidity $3 \mathrm{NTU}$ and $M$. oleifera reduced the turbidity by $93 \%$, at a concentration of $100 \mathrm{mg} / \mathrm{l}$. At a

of MO, JC, and GG on Kemssie water at To $=49$ NTU. e Effect of $\mathrm{MO}, \mathrm{JC}$, and GG on Dessi water at To $=49 \mathrm{NTU}$

concentration of $50 \mathrm{mg} / \mathrm{l}, \mathrm{J}$. curcas reduced the turbidity by $71 \%$. While the optimum dosage for G. gum was 100 $\mathrm{mg} / \mathrm{l}$, with a turbidity reduction of $71 \%$. With water of very low turbidity like that of Dessi (Fig. 2e), which had an initial turbidity of $1 \mathrm{NTU}$, an optimum dosage of $50 \mathrm{mg} / \mathrm{l}$ for all extracts was obtained. M. oleifera and G. gum produced $100 \%$ turbidity reduction and $88 \%$ for $J$. curcas.

\section{Effect of Moringa oleifera}

Overall, the Moringa oleifera powder produced better results than the other two extracts. To ensure validity of the data, two of the wells (Kemssie and Hrbo) were resampled at times of high turbidity (i.e. after period of prolonged rainfall). These results are presented in Fig. 3 and showed that a turbidity reduction in the range of 97-100 \% was achieved. In particular, the water from Nluka had an initial turbidity of 219 NTU and looked very turbid together with a brownish colour. At a concentration of $250 \mathrm{mg} / \mathrm{l} \mathrm{M}$. oleifera, the water was very clear. At 


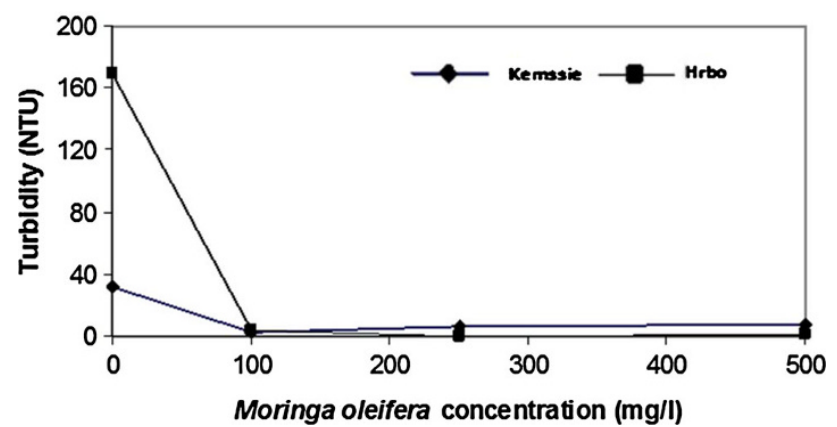

Fig. 3 Effect of MO on Kemssie and Hrbo water at To $=219$ NTU

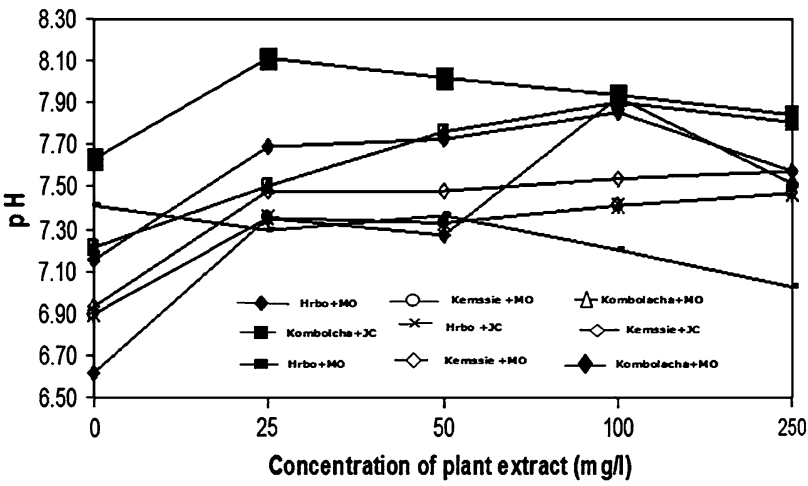

Fig. 4 Effect of MO, JC, and GG on Hrbo, Kemssie and Kombolcha water

higher concentrations $+500 \mathrm{mg} / \mathrm{l}$, the coagulated water had a milky colour. The appropriate concentration ranged from 100 to $250 \mathrm{mg} / \mathrm{l}$. The control had a turbidity reduction of $14 \%$ indicating that just stirring the water, allowing it to settle and then filtering can reduce turbidity of water to a certain extent. Turbidity reduction for Kemssie water which had an initial turbidity of 39 NTU ranged from 72 to $93 \%$, with an average of $82 \%$. The reduction of turbidity in the control was $18 \%$.

It was noted that in $92 \%$ of the samples the $\mathrm{pH}$ of the water increased with dose level shown in Fig. 4. This is in agreement with $M$. oleifera results by $\mathrm{Ng}$ et al. (2006). It was noted that the $\mathrm{pH}$ of water treated by Alum decreased from 6.6 to 5.6 meaning that chemicals needed to be added to raise the $\mathrm{pH}$ of water to the required guideline value. An attribute of G. gum was that it produced very clear supernatant. Most of the solids accumulated at the bottom of the beakers, even at the highest concentration of $500 \mathrm{mg} / \mathrm{l}$, while suspended solids could be seen with $M$. oleifera and $J$. curcas at concentrations as low as $100 \mathrm{mg} / \mathrm{l}$.

Effect on reduction of coliforms

The reduction in coliforms with different concentrations of M. oleifera was also determined. Previously other research

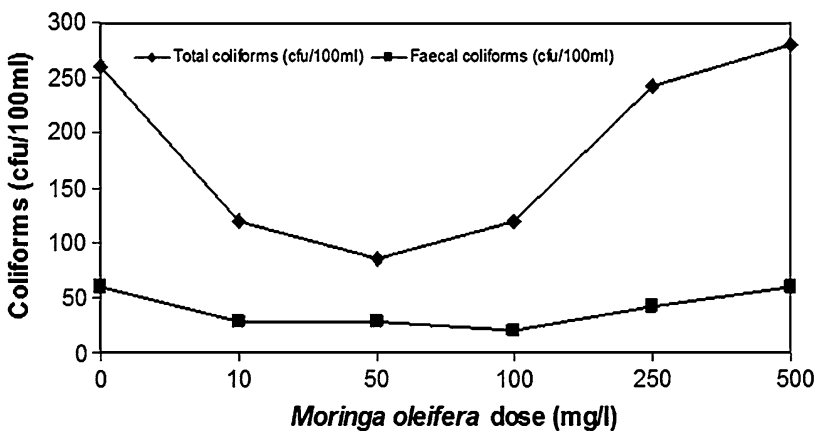

Fig. 5 Effect of MO concentrations on coliforms reduction at $100 \mathrm{mg} / \mathrm{l}$

reported using aqueous and organic extracts of $M$. oleifera Lam (Anith et al. 2011; Sarin et al. 2010). In general, there was a reduction in the number of coliforms and Escherichia coli as shown in Fig. 4. The number of total coliforms was reduced from 260 to $86 \mathrm{cfu} / 100 \mathrm{ml}$ at $50 \mathrm{mg} / \mathrm{l}$. Similarly, the number of $E$. coli was reduced from 60 to $20 \mathrm{cfu} / 100 \mathrm{ml}$ at $100 \mathrm{mg} / \mathrm{l}$. The antimicrobial properties of the seeds of M. oleifera which were found to have inhibitory activity against a number of pathogens (Anwar and Rashid, 2007; Jamil et al. 2007; Kebreab et al. 2005; Lockett et al. 2000) (Fig. 5).

\section{Conclusions}

Moringa oleifera, J. curcas and G. gum reduce turbidity of water. The reduction efficiency is higher for more turbid waters. Turbidity reduction exceeding $90 \%$ was achieved for all the three extracts on shallow well water with an initial turbidity of about 50 NTU. M. oleifera exhibited the most favourable results followed by G. gum and lastly $J$. curcas. The results indicated that $M$. oleifera can reduce turbidity of shallow well water. M. oleifera results for more turbid water $(>200$ NTU) were better than less turbid water. It was noted that $\mathrm{pH}$ of the samples increased as the concentration of the extracts increased. There was, in general, an overall reduction in the number of coliforms and $E$. coli after the water had been treated with $M$. oleifera.

Open Access This article is distributed under the terms of the Creative Commons Attribution License which permits any use, distribution, and reproduction in any medium, provided the original author(s) and the source are credited.

\section{References}

Aho IM, Lagasi JE (2012) A new water treatment system using Moringa oleifera seed. Am J Sci Ind Res 3(6):487-492 
American Water Works Association (AWWA) (1995) Standard methods for the examination of water and wastewater. American Public Health Association Inc., New York

Anith JR, Velliyu KG, Sangilimuthu AY, Sudarsanam D (2011) Antimicrobial activity of Moringa oleifera (Lam.) root extract. J Pharm Res 4:1426-1427

Anwar F, Rashid U (2007) Physico-chemical characteristics of Moringa oleifera seeds and seed oil from a wild provenance of Pakistan. Pak J Biol Sci 39:1443-1453

Broin M, Santaella C, Cuine S, Kokou K, Peltier G, Joet T (2002) Flocculent activity of a recombinant protein from Moringa oleifera Lam. Seeds. Appl Microbiol Biotechnol 60:114-119

Dzwairo B, Hoko Z, Love D, Guzha E (2006) Assessment of the impacts of pit latrines on groundwater quality in rural areas: a case study from Marondera district, Zimbabwe. Phys Chem Earth J 31:779-788

Fahey JW (2005) Moringa oleifera: a review of the medicinal evidence for its nutritional, therapeutic and prophylactic properties. Trees life $\mathrm{J}$ 1:5

Francis JK, Liogier HA (1991) Naturalized exotic tree species in Puerto Rico. USDA Forest Service General Technical Report SO-82, Southern Forest Experimental Station, (New Orleans, LA, USA), p 12

Jamil A, Shahid M, Khan MM, Ashraf M (2007) Screening of some medicinal plants for isolation of antifungal proteins and peptides. Pak J Bot 39:211-221

Kalogo Y, Rosillon F, Hammer F, Verstraete W (2000) Effect of a water extract of Moringa oleifera seeds on the hydrolytic microbial species diversity of a UASB reactor treating domestic wastewater. Lett Appl Microbiol 31:259-264

Kawo AH (2007) Water purification potentials and in vivo toxicity evaluation of the aqueous and petroleum ether extracts of Calotropis procera, Latex and Moringa oleifera Lam seed powder. PhD thesis, Microbiology Unit, Department of Biological Sciences, Bayero University, Kano

Kebreab AG, Gunaratna KR, Henriksson H, Brumer H, Dalhammar GA (2005) Simple purification and activity assay of the coagulant protein from Moringa oleifera seed. Water Res 39:2338-2344

Litherland S (1995) Science: vegetable pods may help solve third world's water woes. Inter Press Service, Washington, DC. Also available at http://treesforlife.org/moringa/uses_water_lgscale_ article.htm. Last accessed on 01/06/2004

Lockett CT, Calvet CC, Grivetti LE (2000) Energy and micronutrient composition of dietary and medicinal wild plants consumed during drought: Study of rural Fulani, Northeastern Nigeria. Int J Food Sci Nutr 51:195-208

Lungu K, Morse T, Grimason AM (2008) Ecological sanitationimplementation opportunities and challenges in Chikwawa, Malawi. Environment and Health International. Magazine of the International Federation of Environmental Health, Congress 10(2): $1-7$

Madsen M, Schlundt J, Omer EFE (1987) Effect of water coagulation by seeds of Moringa oleifera on bacterial concentrations. J Tropol Med Hyg 90:101-109

Mangale SM, Chonde SG, Jadhav AS, Raut PD (2012) Study of Moringa oleifera (Drumstick) seed as natural absorbent and antimicrobial agent for river water treatment. J Nat Prod Plant Resour 2(1):89-100

Masangwi SJ, Morse T, Ferguson G, Zawdie G, Grimason AM, (2008) A preliminary analysis of the Scotland-Chikwawa health initiative project on morbidity. Environment and Health International. Magazine of the International Federation of Environmental Health, Congress 10(2):10-22

Pritchard M, Mkandawire T, O'Neill JG (2008) Assessment of groundwater quality in shallow wells within the Southern districts of Malawi. Phys Chem Earth J 33:927-935

Muyibi SA, Evison LM (1995) Moringa oleifera seeds for softening hard Water. Water Res 29(4):1099-1105

Ng SC, Katayon S, Megat Mohd Noor MJ, Asma M, Abdul Ghani LA, Thamer AM, Azni I, Ahmad J, Khor BC, Suleymen AM (2006) Effects of storage conditions of Moringa oleifera seeds on its performance in coagulation. Bioresour Technol 97:1455-1460

Onsare JG, Kaur H, Arora DS (2013) Antimicrobial activity of Moringa oleifera from different locations against some human pathogens. Acad J Med Plants 1(5):080-091

Paqualab Manual (2005) Operating instructions. ELE International, 440-005 Issue 1

Peavy HS, Rowe DR, Tchobanoglous G (1985) Environmental engineering. McGraw-Hill Inc, New York

Pritchard M, Mkandawire T, O’Neill JG (2007) Biological, chemical and physical drinking water quality from shallow wells in Malawi: case study of Blantyre, Chiradzulu and Mulanje. Phys Chem Earth J 32:1167-1177

Sanghi R, Bhattacharya B, Dixit A, Singh V (2006) Ipomoea dasysperma seed gum: an effective natural coagulant for the decolorization of textile dye solutions. J Environ Manag 81(1):36-41

Sarin R, Manvi M, Sapna B (2010) Evaluation of antibacterial potential of stem bark of M. oleifera Lam. Bioscience 1:89-94

Shulz CR, Okun DA (1984) Surface water treatment for communities in developing countries. Wiley, London

The Plant List, Version 1 (2010) Published on the Internet. http:// www.theplantlist.org/. Accessed 1st Jan

UNESCO (2007) UNESCO water portal newsletter No. 161: Waterrelated Diseases. http://www.unesco.org/water/news/newsletter/ 161.shtml

World Bank (2013) The World Bank Annual Report. http://data. worldbank.org/about/country-classifications

World Health Organisation (WHO) (2006) Guidelines for drinkingwater quality, First Addendum to Third Edition, vol 1 Recommendations. Available from: http://www.who.int/water sanitation_health/dwq/gdwq0506.pdf. Accessed June 2008

World Health Organisation (WHO) (1997) Guidelines for drinking water quality, 2nd edn, vol 3. Surveillance and control of community supplies

World Health Organisation (WHO) (2004) Guidelines for drinking water quality. Volume 1 Recommendations (3rd edn). Geneva, Switzerland

Yongabi KA (2008) Studies on the potential use of medicinal plants and macrofungi (lower plants) in water and wastewater purification. www.biotech.kth.se/iobb/news/kenneth/archive.html. Accessed June 2008 